\title{
OBITUARY
}

\section{Professor John M Goldman, 1938-2013: Gentleman and Scholar}

Leukemia (2014) 28, 1175-1176; doi:10.1038/leu.2014.36; published online 21 March 2014

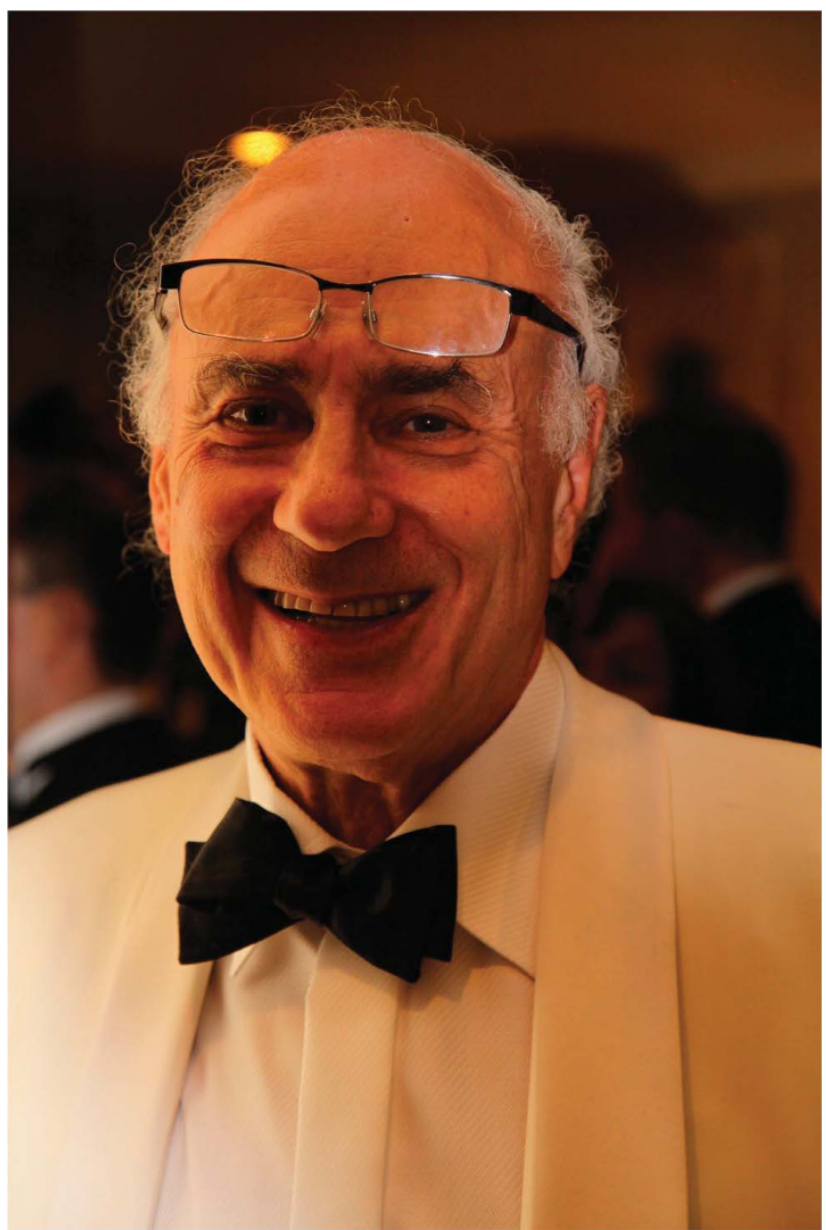

When beggars die there are not comets seen; The heavens themselves blaze forth the death of princes.

Shakespeare, Julius Caesar

John M Goldman, a towering figure in hematology in the United Kingdom and globally for a generation, died in London on Christmas eve. John was born in London in 1938. He read Classics at Oxford but was abducted (his description) to Magdalene College to read Medicine. John completed his medical training at St Bartholomew Hospital, London, trained briefly in surgery, oncology and radiation therapy in the United Kingdom and then moved to the United States taking postgraduate positions at the University of Miami (with Professor Adele Yunis) and Harvard University (with Professor George Canellos).

In 1971, John joined a distinguished group of hematologists in the Department of Haematology at Hammersmith Hospital, including Sirs John Dacie and David Galton, Professors Victor Hoffbrand and Daniel Catovsky and others. His major focus was chronic myeloid leukemia. CML was incurable when he began and he tried many approaches starting with autotransplants of chronic phase blood cells, then transplants from HLA-identical siblings, followed by transplants from HLA-matched unrelated donors. This worked but the price of cure was high, and most persons with CML were either too old or lacked a suitable donor.

In 1983, the molecular cause of CML was identified (by Professors Eli Canaani, Robert Peter Gale and others). In 1990, Goldman promoted the promising preclinical research of Professor Brian Druker and colleagues who had developed imatinib, a tyrosine kinase inhibitor, directed against the oncogenic protein causing CML. The drug worked well in preclinical models but no drug company was interested to develop it for commercial reasons. Much like the story of Florey and Chain who developed penicillin but had to travel to the United States to find a drug company willing to produce it (Eli Lilly \& Co.) despite its potential to become an advantage for the allies in the World War II, Goldman flew to Basel to persuade Novartis to manufacture imatinib. He succeeded, and with colleagues at Hammersmith Hospital, especially Professor Jane Apperley, he conducted many of the early clinical trials. Imatinib and its successors are now widely used to treat $C M L$ and have extended the lives of thousands of people with CML worldwide. Some may be cured. He also took a sabbatical in 1985 at the Whitehead Institute at MIT with Professors David Baltimore, George Daley and Richard van Etten.

John did many other important things. In 1984, (with Gale) he established Bone Marrow Transplantation, a widely read and highly regarded journal. (He also had a long-standing close relationship with Nicole Killman, his colleague and co-editor at Nature Publishing Group, whom he often met in London, Paris and Cannes.) He co-founded, with many senior European hematologists, several professional organizations promoting research in blood disorders and transplantation including the European Hematology Association and the European Bone Marrow Transplant society and was president of both. John was also a strong supporter and Chairman of the International Bone Marrow Transplant Registry and Center for International Blood and Marrow research. With Professor Alejandro Madrigal, he established the Anthony Nolan Trust Donor Registry of more than 500000 volunteers. This registry has been used to help people needing transplant in the United Kingdom and worldwide. John and his colleagues created LEUKA, a charity to fund leukemia research, including a new outpatient haematology center at Hammersmith Hospital.

Following his retirement from Hammersmith Hospital in 2004, Goldman focused on global health issues. With Professors Timothy Hughes and Jorge Cortes, he developed the International CML Foundation to make innovations in diagnosis, monitoring and therapy available worldwide, especially in developing countries. He spent a year at the National Institutes of Health with Professor John Barrett as the Fogarty Scholar. Lately, he campaigned to reduce cancer drug prices so that people in developing countries could benefit. The World Health Organization predicts that in 2050 more than one-half of cancers will occur in developing countries that are unable to afford proper cancer care at current costs. 
John Goldman received many honors including MA, Oxford, 1968; DM, Oxford, 1981; MRCP, London, 1967; FRCP, London 1979; MRCPath, London 1985; FRCPath, London 1986, Fellow, Acad Medical Sciences, 2000; MD (hc) KU Louvain, 1993; MD (hc), University of Poitiers, 1995; and MD (hc), Charité-Universitätsmedizin, Berlin, 2004.

Professor Goldman was a leader in his field. He published over 800 scientific papers and many books, coordinated an international community of leukemia researchers and fostered a climate of openness, collaboration and intellectual exchange. He mentored a generation of leukemia specialists who now head hematology departments across the United Kingdom and globally, including Professors Jane F Apperley, Steven O'Brien, Charles Craddock, Timothy Hughes and many others.

John Goldman was a skilled physician devoted to his patients. He would roam the labyrinthine corridors of Hammersmith Hospital at all hours reading medical charts and counseling people. Overseas colleagues thought nothing of calling John at 0100 or 0200 hours GMT to discuss a question or simply to chat. No one is certain when (or if) he ever slept.

Professor Goldman was a gentleman and scholar known for his erudition, irony, generosity and modesty. He enjoyed reading Saki, Wilde, Shakespeare, Greek mythology and histories of the Napoleonic wars. He loved skiing, spoke perfect French and traveled extensively. He once drove from London to India with his Oxford classmates. After their party was imprisoned by Iranian authorities, they escaped by drugging their guards. John also tried to solve the problem of the Elgin Marbles by suggesting a duplicate set be made and that each side alternately choose the piece they wanted until two full sets were assembled. No one has come up with a better solution but the quandary remains. Apparently a trickier problem than curing CML. His hilarious article in the Lancet in 1999 described the plight of prominent professors who are obliged to accept invites for keynote speeches at international meetings when, in reality, neither they nor their host really wish them to attend. Not much has changed.

What of John Goldman the man? Complex, like most of us but perhaps a bit more so. After a brief marriage in his twenties, he chose a bachelor life to the disappointment of the many beautiful ladies he courted. He claimed to be a misanthrope but this is difficult to reconcile with his numerous friends, colleagues and protégés. We were close friends for 40 years, and lived together in London, New York and Los Angeles for 1 or 2 months every year, rendezvoused at numerous meetings worldwide picking up a conversation in Kazakhstan, which we had started in Rio, and shared family celebrations. He had a lovely home in Notting Hill with a huge Aga oven in the kitchen but one was likely to find only orange juice (Tropicana with extra bits please), champagne and pâté in his refrigerator. He especially savored Laura's family dinners at 33 Northumberland Place. John was a generous host at home and when he traveled. As one might expect from a slightly eccentric English gentleman, Northumberland was cluttered with art works, Herron rabbits (occasionally live rabbits) and a book collection rivaling the British Library. I often inquired if the vandals who had rubbished his office were apprehended. He had one of the world's largest collections of obsolete electrical cords; archeologists (and Suzy Barry) will take ages to sort these out. Later in life, he developed a passion for his four grandchildren, which proved to be a boon to the toy industries on several continents.

John Goldman was invariably courteous to colleagues, friends and acquaintances. I recall taking him home from Princess Grace Hospital one afternoon immediately after an abdominal operation. We passed a famous Indian restaurant (Star of India on Old Brompton Road) en route and I suggested (thoughtlessly?) we stop for dinner. Always the gentleman, he agreed. I did note he ordered dishes of only two stars on the five-star hotness scale. Sensible I suppose after the major surgery he had undergone; why tempt the Gods?

And this was not an isolated incident. When people approached John with a bizarre idea or scientific hypothesis he was always polite commenting 'That's an interesting idea'. Afterwards he reminded senior colleagues of a quote from Field Marshall Arthur Wellesley, the first Duke of Wellington who, having been addressed by a passerby near Apsley House as 'Mr. Jones, I believe' replied 'If you believe that Sir, you will believe anything'.

John Goldman is survived by his son Jasper and daughters Lucy and Cassie. And by hundreds of grateful colleagues and thousands of people with leukemia who owe their lives to his pioneering efforts. He will be greatly missed. A prince is dead; the Heavens are ablaze.

RP Gale

Division of Experimental Medicine, Department of Medicine, Centre for Haematology, Imperial College London, London, UK E-mail: robertpetergale@gmail.com 